\title{
Pengaruh E-Commerce Terhadap Proses Jual Beli Masyarakat Saat Ini Khususnya Pada Penggunaan Market Online Bukalapak
}

\author{
Muhammad Yasin ${ }^{1}$, Guntur Saseno ${ }^{2}$, Ratih Novinditya Dewi ${ }^{3}$, Nur Dewi Setyowati ${ }^{4}$ \\ ${ }^{1,2,3}$ Mahasiswa Ilmu Komunikasi FISIP, Universitas Merdeka Madiun, Jl.Serayu 79, Madiun, 63133 \\ E-mail: hariyani_nunik@yahoo.com \\ ${ }^{4}$ Dosen Ilmu Komunikasi FISIP, Universitas Merdeka Madiun, Jl.Serayu 79, Madiun, 63133 \\ E-mail:dewisetyowati@unmer-madiun.ac.id
}

\begin{abstract}
E-commerce as a media to buy and sell online begins to develop and is widely discussed because it is recognized to provide various benefits such as ease of transaction, so that transactions can be done anytime and anywhere. Now, many large-scale business and micro, small and medium-sized businesses are starting to implement e-commerce. And the fact that not a few business people have benefited from the success of e-commerce, but also not a few business people who experience failure even some do not know whether e-commerce has achieved success or not. One market place that is often used by people for sale / purchase transactions is BUKALAPAK, is one of the leading markets (online marketplace) in Indonesia which is owned and operated by PT. Bukalapak. With the aim that various conveniences in making transactions and offering discounts can attract public interest to change the style of selling / buying goods manually (physically) to selling / buying goods based on online products.
\end{abstract}

Keywords - : poverty e commerce; market online; Bukalapak.

\section{PENDAHULUAN}

\section{A. Latar Belakang Masalah}

Dunia bisnis semakin maju. Pemasaran merupakan kunci kesuksesan suatu usaha baik bidang jasa maupun produk. Di era modernisasi pemasaran juga tidak dapat hanya dilakukan secara konvensional dengan melakukan pemasaran di lapangan tetapi kita juga harus mulai menggunakan pemasaran modern dengan berbasis online. Perubahan dan perkembangan di dunia IPTEK ini, tidak bisa dipungkiri sedikit banyak pasti mempengaruhi segala aspek kehidupan kita saat sekarang ini. Dengan kata lain, IPTEK adalah suatu hal yang wajib dan krusial bagi kehidupan manusia saat ini, dan untuk masa yang akan datang. Ada seorang ahli mengatakan bahwa, ilmu pengetahuan merupakan pondasi bagi teknologi sedangkan teknologi adalah tulang punggung pembangunan.

E-Commerce atau disebut juga perdagangan elektronik merupakan aktivitas yang berkaitan dengan pembelian, penjualan, pemasaran barang ataupun jasa dengan memanfaatkan sistim elektronik seperti internet ataupun jaringan komputer. Ecommerce juga melibatkan aktivitas berhubungan dengan proses transaksi elektronik seperti transfer dana elektronik, pertukaran data elektronik, sistim pengolahan data inventori dilakukan dengan sistim komputer ataupun jaringan komputer. Dalam teknologi informasi e-commerce dapat dikategorikan sebagai bagian dari e-business dimana e-business memiliki cakupan yang lebih luas baik dari segi aktivitas ataupun jenis jenis kegiatan dilakukannya. Saat ini masyarakat merubah pola jual/beli barang menggunakan system online, dan salah satunya ialah BUKALAPAK, merupakan salah satu pasar (online marketplace) terkemuka di Indonesia dimiliki dan dijalankan oleh PT. Bukalapak.

Seperti halnya situs layanan jual - beli (online), dengan model bisnis customer-to-customer (C2C), Bukalapak menyediakan sarana penjualan dari konsumen-ke-konsumen di mana pun. Siapa pun bisa membuka toko daring untuk kemudian melayani calon pembeli dari seluruh Indonesia baik satuan ataupun dalam jumlah banyak. Pengguna perorangan ataupun perusahaan dapat membeli dan menjual produk, baik baru maupun bekas, seperti sepeda, ponsel, perlengkapan bayi, gawai (gadget), aksesori gawai, komputer, sabak (tablet), perlengkapan rumah tangga, busana, elektronik, dan lain-lain.

\section{B. Rumusan Masalah}

Berdasarkan latar belakang tersebut dapat dirumuskan permasalahan sebagai berikut: Bagaimana pengaruh $e$-commerce terhadap proses jual beli masyarakat saat ini khususnya pada penggunaan market online Bukalapak?

\section{Tujuan Penelitian}

Adapun tujuan dari penelitian ini adalah sebagai berikut :

a) Mengidentifikasi faktor apa saja perkembangan e-commerce merubah proses jual/beli masyarakat saat ini, khususnya pada media market online Bukalapak.

b) Mengidentifikasi faktor apa saja yang mempengaruhi e-commerce terhadap proses jual beli masyarakat saat ini khususnya pada penggunaan market online Bukalapak. 
Website : http://sosial.unmermadiun.ac.id/index.php/sosial

c) Mengetahui cara untuk menghadapi pengaruh e-commerce terhadap proses jual beli masyarakat saat ini khususnya pada penggunaan market online Bukalapak.

\section{Manfaat Penelitian}

Dapat memperluas wawasan dan sekaligus memperoleh pengetahuan empirik mengenai Pelaksana kegiatan dapat mengimplementasikan aplikasi e-commerce untuk transaksi jual/beli masyarakat.

\section{KAJIAN PUSTAKA}

\section{A. Komunikasi Pemasaran Melalui Internet}

Hermawan Kartajaya dalam bukunya New Wave Maketing menginformasikan bahwa internet adalah solusi efektif menarik dan memperkuat komunikasi customer. Hal ini didasari oleh banyanya pengguna internet yang akan terus berkembang dari waktu ke waktu, ditambah lagi akses tanpa batas yang ditawarkan melalui alat-alat yang sebagian besar dimiliki oleh mayarakat. Saat ini akses internet tidak hanya dapat diakses melalui komputer namun juga dapat melalui handphone, sehingga netizen (sebutan untuk pengguna internet) jumlahnya semakin banyak. (Hermawan Kartajaya, New Wave Marketing, Jakarta: PT. Gramedia Pustaka Utama, 2010, hlm 84)

Internet marketing, juga disebut sebagai i-marketing, web marketing, pemasaran online, atau eMarketing, adalah segala usaha yang dilakukan untuk melakukan pemasaran suatu produk atau jasa melalui atau menggunakan media Internet. Kata e dalam e-pemasaran ini berarti elektronik (electronic) yang artinya kegiatan pemasaran yang dimaksud dilaksanakan secara elektronik lewat Internet atau jaringan cyber. Internet telah memberikan banyak manfaat untuk pemasaran, salah satunya adalah biaya yang lebih rendah dan memiliki kemampuan lebih besar untuk mendistribusikan informasi dan media ke khalayak ramai.

Electronic Commerce (e-commerce) adalah proses pembelian, penjualan atau pertukaran produk, layanan dan informasi melalui jaringan komputer. e-commerce adalah bagian dari bisnis elektronik, dimana ruang lingkup e-business lebih luas, tidak hanya komersial tetapi juga mencakup mitra bisnis, layanan pelanggan, lowongan kerja. Selain teknologi jaringan www, teknologi e-commerce juga membutuhkan database atau database (database), e-mail atau surat elektronik (email), dan bentuk teknologi non komputer serta sistem pengiriman lainnya, dan sarana pembayaran e-Commerce. Dengan adanya electronic commerce (e-commerce) maka pelanggan bisa mengakses dan melakukan pemesanan dari berbagai tempat. Mengingat era teknologi mutakhir saat ini adalah pelanggan yang ingin mengakses e-commerce tidak harus berada di suatu tempat, hal itu karena di kota-kota besar di Indonesia ada banyak tempat yang menyediakan fasilitas akses internet hanya dengan menggunakan laptop / notebook. atau oleh Personal Digital Assistant (PDA) menggunakan teknologi wifi. Dengan demikian waktu sekarang sangat dibutuhkan dan perusahaan yang diinginkan untuk menerapkan layanan e-commerceservices. Penggunaan e-commerce di Indonesia masih sangat terbatas. Dari latar belakang itulah maka penulis akan membahas bagaimana pemanfaaatan e-commerce dalam kepentingan bisnis mereka. (Dewi Irmawati, 2011, Politeknik Negeri Sriwijaya)

\section{B. Teori Pemasaran}

Pemasaran adalah suatu system keseluruhan dari kegiatan bisnis yang ditujukan untuk merencanakan, menentukan harga, mempromosikan dan mendistribusikan barang dan jasa yang memuaskan kebutuhan, baik kepada pemebeli yang ada maupun pembeli potensial. Pengertian Pemasaran menurut H. Nystrom "Pemasaran merupakan suatu kegiatan penyaluran barang atau jasa dari tangan produsen ke tangan konsumen". (Marla R. Stafford, Ronald J. Faber, Advertising Promotion and Media, New York: M.E. Sharpe, 2005, hlm 4) Sedangkan Pengertian Pemasaran Menurut Philip dan Duncan "Pemasaran yaitu sesuatu yang meliputi semua langkah yang dipakai atau dibutuhkan untuk menempatkan barang yang bersifat tangible ke tangan konsumen". (Marketing Principles and Methods, 1997, hlm 8)

Menginjak di tahun 2014 saat ini perkembangan teknologi informasi dan komunikasi yang di sebut internet begitu luar biasa manfaatnya dan cepat sekali mengisi kehidupan kita dalam keseharian ini. Internet yang sekarang aksesnya sudah mudah dan lumayan cepat sering dimanfaatkan oleh manusia sebagai alat perdagangan dan penjualan untuk menunjang perdagangan mereka didunia maya. Salah satu trobosan dari internet ini adalah e-commerce atau disebut toko online. Dengan e-commerce ini konsumen yang berada di tempat yg jauh bisa ikut mengaksesnya dan melihat-lihat produknya melalui internet. Sehingga penjualan menggunakan e-commerce ini tidak di batasi ruang dan waktu berbeda dengan toko-toko yang biasa kita lihat di rumah atau di jalan yg dibatasi ruang dan waktu. Penelitian pembuatan e-commerce dan langkah penulis menjadikannya laporan tugas akhir ini dirasa efektif untuk menguraikan masalah-masalah mengenai perdagangan yang dilakukan masyarakat. Pembuatannya bisa menjadi ide alternatif dalam membangun suatu kewirausahaan didunia internet. (Muhammad Amir Udin, 2014, Universitas Dian Nuswantoro, Semarang)

Teori e-commerceLoudon (1998), E-Commerce ialah suatu proses yang dilakukan konsumen dalam membeli dan menjual berbagai produk secara elektronik dari perusahaan ke perusahaan lain dengan menggunakan komputer sebagai perantara transaksi bisnis yang dilakukan. Kalakota dan Whinston (1997)

Meninjau pengertian E-Commerce dari empat perspektif, yaitu: (1) Perspektif komunikasi, E-Commerce ialah sebuah proses pengiriman barang, layanan, informasi, atau pembayaran melalui komputer ataupun peralatan elektronik lainnya. (2) Perspektif proses bisnis, E-Commerce merupakan sebuah aplikasi dari suatu teknologi menuju otomatisasi dari transaksi bisnis dan aliran kerja. (3) Perspektif layanan, E-Commerce ialah suatu alat yang memenuhi keinginan perusahaan, manajemen, dan konsumen 
untuk mengurangi biaya layanan (service cost) ketika meningkatkan kualitas barang dan meningkatkan kecepatan layanan pengiriman. (4) Perspektif online, E-Commerce menyediakan kemampuan untuk membeli dan menjual produk atau barang serta informasi melalui layanan internet maupun sarana online yang lainnya.

\section{III.METODE PENELITIAN}

Penelitian metode deskriptif kualitatif dengan wawancara seluruh pelapak di Kota Madiun yang menggunakan aplikasi Bukalapak dengan teknik observasi, wawancara, dan dokumentasi untuk menggali data. Fokus atau pusat perhatian mengkaji mengenai perhatian konsumen market online terhadap perkembangan jual-beli online saat ini dengan menggunakan aplikasi Bukalapak.com. Adapun yang menjadi kajian dari ketiga fokus perhatiannya, adalah sebagai berikut: (1) Sikap perhatian masyarakat dalam penyampaian pesan iklan, (2) Sikap respon masyarakat atau konsumen dalam tindakan pembelian produknya, (3) Sikap konsumen dalam menyikapi pengaruh dari penggunaan aplikasi tersebut.

\section{IV.HASIL DAN PEMBAHASAN}

\section{A. Deskripsi objek penelitian}

Bukalapak.com adalah penyedia tempat jual-beli online mudah \& terpercaya; yang memberikan jaminan 100\% uang kembali kepada pembeli jika barang tidak dikirimkan oleh pelapak. Situs ini pertama kali dibuat pada awal tahun 2010 oleh mahasiswa ITB. Pengalaman kurang menyenangkan yang didapat ketika berbelanja online melatarbelakangi visi Bukalapak.com untuk menyediakan tempat jual-beli online yang aman bagi semua orang. Semangat itulah yang menjadi alasan seluruh karyawan Bukalapak.com dalam bekerja.

Banyak keuntungan yang bisa didapat jika berjualan di BukaLapak. masyarakat tidak perlu ngerti tentang coding, tidak perlu mengeluarkan biaya untuk nyewa server, dan tidak perlu tahu tentang SEO (Search Engine Optimization). Yang di butuhkan dan harus diketahui adalah cara membuat akun. Tidak perlu waktu lama untuk membuat sebuah akun di BukaLapak.com. Hanya butuh waktu 5 menit atau kurang, maka akun BukaLapak kamu langsung jadi.

Bukalapak merupakan salah satu pasar online (marketplace) terkemuka di Indonesia yang dimiliki dan dijalankan oleh PT. Bukalapak. Seperti halnya situs layanan jual-beli online dengan model bisnis consumer-to-consumer (C2C), Bukalapak menyediakan sarana penjualan dari konsumen ke konsumen di mana pun. Siapa pun bisa membuka toko untuk kemudian melayani calon pembeli dari seluruh Indonesia baik satuan ataupun dalam jumlah banyak. Pengguna perorangan ataupun perusahaan dapat membeli dan menjual produk, baik baru maupun bekas, seperti sepeda, ponsel, perlengkapan bayi, gadget, aksesoris gadget, komputer, tablet perlengkapan rumah tangga, busana, elektronik, dan lain-lain.

Bukalapak didirikan oleh Achmad Zaky pada awal tahun 2010 sebagai divisi agensi digital bernama Suitmedia yang berbasis di Jakarta. Namun, Bukalapak baru berstatus sebagai sebuah Perseroan Terbatas (PT) pada September 2011 dan dikelola oleh manajemen yang dipimpin oleh Achmad Zaky sebagai CEO (Chief Executive Office) dan Nugroho Herucahyono sebagai CTO (Chief Technology Officer).Setelah berdiri kurang lebih setahun, Bukalapak mendapat penambahan modal dari Batavia Incubator (perusahaan gabungan dari Rebright Partners yang dipimpin oleh Takeshi Ebihara, Japanese Incubator dan Corfina Group). Di tahun 2012, Bukalapak menerima tambahan investasi dari GREE Ventures yang dipimpin oleh Kuan Hsu.

Pada bulan Maret 2014, Bukalapak mengumumkan investasi oleh Aucfan, IREP, 500 Startups, dan GREE Ventures. Tidak berselang lama dari pemberitaan tersebut, di tanggal 18 Maret 2014 Bukalapak pun meluncurkan aplikasi selular untuk Android. Aplikasi yang dikenal dengan mobile Bukalapak tersebut diciptakan khusus untuk para penjual untuk mempermudah penjual dalam mengakses lapak dagangannya dan melakukan transaksinya melalui smartphone. Sejak pertama kali diluncurkan sampai dengan Oktober 2016, aplikasi tersebut telah didownload oleh lebih dari 5 juta kali dan masuk dalam 100 Aplikasi Gratis terpopuler di Google Play.

Bukalapak memiliki program untuk memfasilitasi para UKM yang ada di Indonesia untuk melakukan transaksi jual beli secara online. Hal ini dikarenakan transaksi melalui online dapat mempermudah UKM dalam menjual produk-produk yang mereka miliki tanpa harus memiliki toko offline. Untuk yang telah memiliki toko offline, Bukalapak mengharapkan dengan adanya situs tersebut dapat membantu meningkatkan penjualan toko offline tersebut. (Bukalapak from https://www.bukalapak.com/about Diakses 2 Juli 2018, Pukul 10.32 WIB)

\section{B. Strategi Bukalapak:}

Dengan dua juta kunjungan setiap harinya, Bukalapak merupakan salah satu platform e-commerce terbesar di Indonesia. Bukalapak juga mengklaim kalau 800 ribu penjual yang mereka miliki adalah yang terbanyak di antara e-commerce lainnya tanah air.Menurut Muhamad Fajrin Rasyid, Co-Founder sekaligus CFO dari Bukalapak, dalam acara Decode Jakarta Maret 2016 Inilah empat strategi utama mereka:Promosi sebanyak mungkin, Fokus pada perangkat mobile, Analisis Kebisaan Pelanggan, Offline Gathering.

Profit (Keuntungan) Bukalapak, Bukalapak juga mendapatkan profit (keuntungan) dari elemen sebagai contoh adalah berikut ini: (1) Fitur-fitur premium yang disediakan Bukalapak. Contoh: fitur Promote to Top. (2) Selisih dari 3 angka unik di total pembayaran melalui transfer. Contoh: jika total bayar sebenarnya adalah Rp. 500.000 diberikan 3 angka unik di belakangnya menjadi Rp. 500.779. Jika dalam 1 hari ada 100.000 tranksaksi, maka estimasi selisih yang didapatkan oleh Bukalapak adalah Rp. 77.900.000/hari. 
Cara Berbelanja di Bukalapak, adalah sebagai berikut: Cari Barang, Klik Beli, Pembeli mencari barang, Pilih barang yang dinginkan kemudian klik Beli, Shopping Review, Pembayaran, Pembeli melengkapi alamat pemesanan barang, Pembeli dapat melakukan pembayaran ke rekening Bukalapak melalui Buka Dompet, Mandiri ClickPay, BCA KlikPay, CIMB Clicks, Kartu Visa/Mastercard atau Transfer, Pembeli Menerima Barang, Konfirmasi terima barang, Pembeli mengkonfirmasi menerima barang. Cara Berjualan di Bukalapak: Jual Barang, Kelola Transaksi.

Penjual bisa menjual barang dengan harga yang diinginkan Penjual dapat mengelola dan memantau transaksi secara langsung pada halaman Transaksi. Setiap transaksi memiliki 5 status: Menunggu, Dibayar, Dikirim, Diterima, dan Selesai: Pengiriman Barang, Terima uang dan Feedback. Penjual akan menerima e-mail, notifikasi, dan sms setiap pembeli berhasil melakukan pembayaran. Pada tahap ini status transaksi adalah Dibayar. penjual dapat mengemas barang daganganmu lalu mengirimkannya. (melalui kurir, dll) Penjual akan menerima uang pembayaran dan feedback setelah pembeli menerima barangmelakukan pembayaran. Pada tahap ini status transaksi adalah Dibayar. penjual dapat mengemas barang dagangan lalu mengirimkannya (melalui kurir, dll)

Fitur umum yang ada pada situs Bukalapak.com diantaranya:

a) Registrasi : Untuk pengguna yang ingin mendaftarkan diri di Bukalapak, setelah mendaftar diperlukan validasi melalui email.

b) Login : Untuk login pengguna yang sudah mendaftarkan diri sebelumnya.

c) Kategori Produk: Menampilkan kategori produk yang dijual, dalam kategori juga terdapat sub-kategori, untuk memudahkan pengguna mencari barang yang diinginkan.

d) Premium Account : Fitur berbayar ini menawarkan fasilitas lebih untuk mengetahui statistik penjualan hingga melihat tren pasar yang tepat untuk meningkatkan transaksi penjualan pengguna.

e) Komunitas : Forum komunitas pengguna bukalapak.

f) Blog : Blog Bukalapak yang berisi pengumuman Bukalapak, promo, serta tips-tips dari Bukalapak.

g) Buka Bantuan : Halaman panduan untuk pengguna Bukalapak, berisi FAQ (Frequently Asked Questions) sampai fitur-fitur yang ada di Bukalapak.

h) Keranjang Belanja : Untuk melihat barang apa saja yang sudah diklik beli.

i) Pesan : Fitur pesan, bisa digunakan oleh pembeli untuk berkomunikasi dengan penjual.

j) Transaksi : Data transaksi pengguna.

k) Jual Barang : Untuk pengguna yang ingin membuka lapak.

1) My Lapak : My lapak adalah fitur untuk pengguna yang memiliki lapak (penjual) berisi ringkasan akun, data lapak, data transaksi dll.

m) PromotePush : Untuk mempromosikan lapak, fitur ini fungsinya mirip dengan teknik sundul di Kaskus.

n) Feedback: Umpan balik dari pembeli, semakin baik rating yang diberikan semakin baik reputasi penjual.

o) Beli Pulsa dan Paket Data

Buka Lapak melayani pembelian pulsa dan paket paket data, cukup memasukan nomor telepon dan nominal, peserta bisa mendapatkan pulsa setelah melakukan pembayaran.

p) Buka Dompet

Saldo khusus untuk di Bukalapak, bisa top up dan bisa dicairkan sewaktu-waktu.

\section{Kelebihan dan Kekurangan Situs Bukalapak.com}

Kelebihan dan kekurangan yang ada pada situs penjualan Bukalapak.com diantaranya: adapun kelebihannya (1) Notifikasi SMS setiap ada pesanan : Penjual akan mendapatkan SMS (jaringan GSM) setiap ada pesanan. Penjual bisa fokus jualan online tanpa buang-buang waktu melayani calon pembeli yang tidak serius. (2) Feedback positif setiap transaksi sukses : Penjual akan mendapatkan feedback positif secara otomatis dari sistem walaupun pembeli tidak memberikan feedback saat transaksi. (3) Kepastian menerima uang pembayaran : Penjual langsung menerima uang pembayaran setelah pembeli mengkonfirmasi penerimaan barang atau $1 \times 24$ jam setelah barang terkirim menurut kurir. (4) Prioritas di mesin pencarian : Setiap halaman barang penjual telah melalui proses SEO (Search Engine Optimization) agar tampil lebih unggul di mesin pencarian seperti Google dan lainnya. (5) Perhitungan ongkos kirim otomatis : Penjual tidak perlu repot menghitung ongkos kirim karena sistem akan otomatis menghitung ongkos kirim yang harus dibayar oleh pembeli. (6) Edukasi Kewirausahaan Online : Bukalapak terus membangun semangat kewirausahaan kepada pelapak dan pembeli dengan memberikan tips dan trik jualan online.

Kekurangan : (1) Jika dibandingkan Pesaing sejenis, Bukalapak kurang gencar memberikan promo kepada pelanggan. (2) . Barang yang dijual tidak terjamin keaslian merknya. (3). Banyak oknum nakal yang membagi link ke setiap akun untuk meretas, seperti mencuri data, dan saldo korban (https://www.google.co.id/amp/s/silviosilviando.wordpress.com/2016/12/03/analisisweb-e-commerce-bukalapak/amp/ diakses 14 Mei 2018Pkl. 10.49 wib)

Beberapa peneliti telah banyak mengkaji dan berusaha memberikan masukan untuk pengembangan UMKM di Indonesia. Peneliti tersebut diantaranya dilakukan oleh Supriyanto (2006:1) menyimpulkan dalam penelitiannya ternyata UMKM mampu menjadi solusi penanggulangan kemiskinan di Indonesia. Penanggulangan kemiskinan dengan cara mengembangkan UMKM memiliki potensi cukup baik, karena ternyata sektor UMKM memiliki kontribusi besar dalam penyerapan tenaga kerja, yaitu menyerap lebih dari 99,45\% tenaga kerja dan sumbangan terhadap PDB sekitar $30 \%$. 
Upaya untuk memajukan dan mengembangkan sektor UMKM akan dapat menyerap lebih banyak lagi tenaga kerja yang ada dan tentu saja akan dapat meningkatkan kesejahteraan para pekerja yang terlibat di dalamnya sehingga dapat mengurangi angka pengangguran. Dan pada akhirnya akan dapat digunakan untuk pengentasan kemiskinan (Cano Ekonomos, 2017:52).

Presiden Yudhoyono pada tanggal 26 Pebruari 2005 mencanangkan Program Aksi Pengentasan Kemiskinan melalui pemberdayaan UMKM, ada 4 jenis kegiatan pokok yang akan dilakukan yaitu sebagai berikut: (1) Penumbuhan iklim usaha yang kondusif. (2) Pengembangan sistem pendukung usaha, (3) Pengembangan wirausaha dan keunggulan kompetitif, (4) Pemberdayaan Usaha skala Mikro (Cano Ekonomos, 2017:52).

Kemudian peneliti Darwanto (2013:142-149) melakukan pengamatan terhadap perutumbuhan UMKM dalam perekonomian di Indonesia. UMKM sebagai bagian dari perekonomian juga harus lebih meningkatkan daya saing dengan melakukan inovasi. Keunggulan bersaing berbasis inovasi dan kreativitas harus lebih diutamakan karena mempunyai daya tahan dan jangka waktu lebih panjang.

Menurut Peneliti dilihat dari penjelasan di atas, UMKM sebagai bagian dari perekonomian yang mampu mengatasi permasalahan kemiskinan di Indonesia, tetapi UMKM saat ini harus mempunyai suatu terobosan dan inovasi yang baru agar bisa bertahan di persaingan pasar saat ini. Usaha Mikro usaha produktif milik orang perorangan dan/atau badan usaha perorangan. Usaha Kecil adalah usaha ekonomi produktif yang berdiri sendiri, yang dilakukan oleh orang perorangan atau badan usaha yang bukan merupakan anak perusahaan atau bukan cabang perusahaan yang dimiliki, dikuasai, atau menjadi bagian baik langsung maupun tidak langsung dari usaha menengah atau usaha besar yang memenuhi kriteria Usaha Kecil sebagaimana dimaksud UU Nomor 20 tahun 2008 tentang Usaha Mikro, Kecil,dan Menengah).Usaha Menengah adalah usaha ekonomi produktif yang berdiri sendiri, yang dilakukan oleh orang perseorangan atau badan usaha yang bukan merupakan anak perusahaan atau cabang perusahaan yang dimiliki, dikuasai, atau menjadi bagian baik langsung maupun tidak langsung dengan Usaha Kecil atau usaha besar dengan jumlah kekayaan bersih atau hasil penjualan tahunan. Usaha Besar adalah usaha ekonomi produktif yang dilakukan oleh badan usaha dengan jumlah kekayaan bersih atau hasil penjualan tahunan lebih besar dari Usaha Menengah, yang meliputi usaha nasional milik Negaraatau swasta, usaha patungan, dan usaha asing yang melakukan kegiatan ekonomi di Indonesia. (peuyeumcipatat.blogspot.com/2013/05/pengertiankriteria-dan-klasifikasi-umkm.html? diakses 14 Mei 2018 pukul 12.08 wib).

Tabel 1

Kriteria UMKM

\begin{tabular}{|l|l|l|l|}
\hline \multirow{2}{*}{ No. } & \multicolumn{1}{|c|}{ URAIAN } & \multicolumn{2}{|c|}{ KRITERIA } \\
\cline { 3 - 4 } & & ASSET & OMZET \\
\hline 1 & USAHA MIKRO & Maks. 50 Juta & Maks. 300 Juta \\
\hline 2 & USAHA KECIL & > 50 Juta -500 Juta & $>$ 300 Juta - 2,5 Miliar \\
\hline 3 & USAHA MENENGAH & > 500 Juta -10 Miliar & $>2,5$ Miliar - 50 Miliar \\
\hline
\end{tabular}

\section{Klasifikasi UMKM}

Dalam perspektif perkembangannya, UKM dapat diklasifikasikan menjadi 4 (empat) kelompok yaitu:

a) Livelihood Activities, merupakan UKM yang digunakan sebagai kesempatan kerja untuk mencari nafkah, yang lebih umum dikenal sebagai sektor informal. Contohnya adalah pedagang kaki lima.

b) Micro Enterprise, merupakan UKM yang memiliki sifat pengrajin tetapi belum memiliki sifat kewirausahaan.

c) Small Dynamic Enterprise, merupakan UKM yang telah memiliki jiwa kewirausahaan dan mampu menerima pekerjaan subkontrak dan ekspor.

d) Fast Moving Enterprise, merupakam UKM yang telah memiliki jiwa kewirausahaan dan akan melakukan transformasi menjadi Usaha Besar (UB).

\section{E. Penyajian \& Analisa}

Untuk mengetahui bagaimana pengaruh aplikasi e-commerce Bukalapak terhadap system jual beli online pada saat ini. Penulis telah melakukan penelitian UMKM di kota madiun yang menggunakan aplikasi Bukalapak. Dalam penelitian ini penulis menggunakan Teknik observasi, wawancara, dan dokumentasi untuk menggali data sebanyak - banyaknya dan seobjektif mungkin. Berikut hasil wawancara dengan UMKM yang ada di Bukalapak, dengan menggunakan variabel X, dengan indikator:

a) Pemasaran/Marketing

1) Kesan setelah menggunakan aplikasi e-commerce bukalapak.

Hasil wawancara:

Kesannya ya baik saja, karena kita melihat Bukalapak adalah toko-toko terbesar dengan banyak peminat. (Wawancara dengan Syarif Putranto A Tgl 28 Mei 2018 Jam 11.00 WIB)

Kesannya Bukalapak itu milik Indonesia, berbeda dengan aplikasi lain yang dijajah pihak asing. Jadi dengan menggunakan Bukalapak saya lebih percaya dengan barang dan kiriman pasti tidak pernah mengecewakan. (Wawancara Maria Dita Tgl 30 Mei 2018 Jam 12.35 WIB)

Kesannya sangat membantu. Penjual dan pembeli sama-sama merasakan keuntungan, ibarat seperti dipasar tapi secara online. (Wawancara Rizal Saputra Tgl 31 Mei 2018 Jam 11.15 WIB) 
Website : http://sosial.unmermadiun.ac.id/index.php/sosial WIB)

Dengan adanya bukalapak ini toko banyak dikenal orang. (Wawancara Septiyan A.K Tgl 02 Juni 2018 Jam 11.30

Jualan dibukalapak itu semakin banyak membeli paket push semakin banyak juga produk yang terjual. (Wawancara Arista Kurnia Rohmah Tgl 04 Juni 2018 Jam 11.50 WIB)

Jualan dibukalapak itu sangat mudah, tidak ribet seperti buka toko offline. (Wawancara Indra Tri Hutomo Tgl 06 Juni 2018 Jam 12.15 WIB)

Dapat customer seluruh Indonesia, Admin Bukalapak sangat fast respon, memiliki pelayanan yang baik, dan dapat meningkatkan penjualan. (Wawancara Agus Danang S. Tgl 07 Juni 2018 Jam 12.25 WIB)

Usahanya jadi lebih dikenal orang secara nasional. Pembelinya tidak hanya regional Jawa Timur. Tapi juga dari seluruh Indonesia. (Wawancara Ahmad Tgl 09 Juni 2018 Jam 12.51 WIB)

Sangat mudah dan bagusnya Bukalapak melarang perdagangan terlarang misalnya obat-obat racun hewan. (Wawancara Toha Ismail Tgl 11 Juni 2018 Jam 13.05 WIB)

Menurut saya simple dan mudah saat menjual produk di Bukalapak. (Wawancara Dewi Ana Tgl 25 Juni 2018 Jam 13.05 WIB)

Dari beberapa jawaban informan pengelola UMKM yang ada di aplikasi Bukalapak menyatakan kesannya bahwa sebagian besar pengelola UMKM di Kota Madiun merasa sangat puas dengan adanya Bukalapak, karena menurut mereka Bukalapak adalah situs jual beli yang terpercaya di Indonesia dan merasa terbantu karena mampu memberikan peningkatan pada nilai penjualan mereka.

2) Hal yang membuat tertarik menggunakan aplikasi e-commerce Bukalapak.

Hasil wawancara:

Sebagai ajang untuk memasarkan produk, karena heatnya Bukalapak tinggi dari sisi penjualan maka terkesan aman, saling bertanggung jawab antara penjual dan pembeli juga kurirnya dan juga di Bukalapak sudah terjamin barang yang di beli akan datang sesuai tujuan, dengan barang tidak kurang suatu apapun. (Syarif Putranto A Tgl $28 \mathrm{Mei}$ 2018 Jam 11.00 WIB)

Promosi ya, iklan juga iya. Saling tukar info penjualan ke komunitas-komunitas. (Wawancara Maria Dita Tgl 30 Mei 2018 Jam 12.40 WIB)

Aplikasi sangat familiar sehingga mampu mengikuti selera masyarakat. (Wawancara Rizal Saputra Tgl 31 Mei 2018 Jam 11.20 WIB)

Bukalapak saat ini itu dimata masyarakat sudah menjadi prioritas belanja dengan system online. (Wawancara Septiyan A.K Tgl 02 Juni 2018 Jam 11.33 WIB)

Ya itu aku dulu cuma denger-denger, trus saya kepo akhirnya saya install aplikasi bukalapak, oh jadi gini to jual beli dibukalapak itu. Dan disemarang itu ada yang jual batik grosir dengan harga dibawah rata-rata dengan kualitas yang bagus, dan produk ini kenapa nggk saya jual dibukalapak aja gitu. (Wawancara Arista Kurnia Rohmah Tgl 04 Juni 2018 Jam 11.55 WIB)

Mengikuti orang lain yang sudah mencobanya. (Wawancara Indra Tri Hutomo Tgl 06 Juni 2018 Jam 12.20 WIB)

Bukalapak aplikasi yang menjadi pilihan masyarakat. (Wawancara Agus Danang S. Tgl 07 Juni 2018 Jam 12.30 WIB)

Aplikasinya tidak berbayar, transaksi serta infonya mudah, keamanan transaksi serta info rahasia/penting penjual dan pembeli terjaga. (Wawancara Ahmad Tgl 09 Juni 2018 Jam 12.58 WIB)

Transaksinya mudah nggak ribet dan ada peraturan penalty. (Wawancara Toha Ismail Tgl 11 Juni 2018 Jam 13.10 WIB) Mengikuti tren saat ini. (Wawancara Dewi Ana Tgl 25 Juni 2018 Jam 13.10 WIB)

Dari beberapa jawaban informan pengelola UMKM yang ada di aplikasi Bukalapak menyatakan bahwa sebagian besar pengelola UMKM di Kota Madiun yang membuat mereka tertarik menggunakan aplikasi Bukalapak adalah karena aplikasinya tidak berbayar, transaksi serta infonya mudah, keamanan transaksi serta info rahasia/penting penjual dan pembeli terjaga. Dan yang pasti mudah penggunaan dalam memasarkan produk mereka.

b) Penjualan

1) Strategi penjualan yang digunakan agar masyarakat tertarik membeli produk UMKM di Bukalapak.

Hasil Wawancara:

Bukalapak itu terkenal murah ya, promosinya sih berupa brosur, menginfokan di brosur tersebut, dan mempublish ke masyarakat tentang toko kami. Dan toko kami sendiri mengikuti jaman yang sudah semakin canggih dan banyak dibutuhkan. (Syarif Putranto A Tgl 28 Mei 2018 Jam 11.15 WIB)

Menggunakan paket "push" yang ada di Bukalapak, juga menggunakan iklan. (Wawancara Maria Dita Tgl 30 Mei 2018 Jam 12.44 WIB)

Barang yang tidak laku dihapus, atau diganti atau bisa juga di diskon agar konsumen tertarik. Di Bukalapak kan juga ada aplikasi "push" kan gunanya agar barang yang dijual berada di atas atau paling atas pencariannya (Wawancara Rizal Saputra Tgl 31 Mei 2018 Jam 11.22 WIB)

Dengan menggunakan jasa yang ada dibukalapak, seperti upgrade lapak serta promote push. (Wawancara Septiyan A.K Tgl 02 Juni 2018 Jam 11.37 WIB) 
Website : http://sosial.unmermadiun.ac.id/index.php/sosial

Strategi saya berjualan dibukalapak itu saya memainkan hashtag dan judul produknya, misal atasan baju batik parang murah. Ya sebisa mungkin produk saya mudah dicari konsumen dibukalapak. (Wawancara Arista Kurnia Rohmah Tgl 04 Juni 2018 Jam 12.05 WIB)

Hanya mengandalkan system yang ada dibukalapak untuk menarik konsumen. (Wawancara Indra Tri Hutomo Tgl 06 Juni 2018 Jam 12.20 WIB)

Menggunakan sistem promosi, dengan upgrade lapak. (Wawancara Agus Danang S. Tgl 07 Juni 2018 Jam 12.35 WIB)

Foto yang menarik, memberikan diskon berkala untuk tiap item, push and promote. (Wawancara Ahmad Tgl $09 \mathrm{Juni}$ 2018 Jam 13.05 WIB)

Memasang produk yang sebanyak-banyak mungkin dan menjadi costumer itu adalah saudara. (Wawancara Toha Ismail Tgl 11 Juni 2018 Jam 13.18 WIB)

Dengan memberikan link yang mengarah langsung ke lapak toko melalui social media. (Wawancara Dewi Ana Tgl 25 Juni 2018 Jam 13.15 WIB)

Dari beberapa jawaban informan pengelola UMKM yang ada di aplikasi Bukalapak menyatakan bahwa sebagian besar pengelola UMKM di Kota Madiun yang dari semua hasil survei dan wawancara melakukan strategi penjualan dengan menggunakan paket "push" yang tersedia di Bukalapak itu sendiri, hal ini dilakukan karena paket itu berfungsi sebagai menjadikan barang atau produk jualan pelapak akan berada pada puncak daftar pencarian barang satu Indonesia agar mudah di cari dan menguntungkan pelapak tersebut.

2) Cakupan Pasar penjualan produk yang ada di Bukalapak.

Hasil Wawancara:

Seluruh Indonesia, sampai saat ini belum sampai ke luar negeri yang paling jauh Papua dan kebanyakan dari luar Pulau Jawa. Dan target pemasarannya sendiri dari sisi usia belum bisa di cek karena di Profil Usernya di Bulakapak bersifat umum, tapi kalau dilihat dari cara mengirim pesan sepertinya kalangan anak muda. Sedangkan kalau servis gitu kebanyakan orang-orang berbisnis. (Syarif Putranto A Tgl 28 Mei 2018 Jam 11.20 WIB)

Kebanyakan sih luar Jawa ya, karena orang luar Jawa itu nggak mempermasalahkan harga seperti contoh di wilayah Papua dan Kalimantan, berbeda dengan wilayah Jawa karena sudah banyak pasar jadi mereka memilih mana toko yang murah. (Wawancara Maria Dita Tgl 30 Mei 2018 Jam 12.48 WIB)

Usia sekolah, orang kerja. Dan toko ini juga bisa mengirim sampai wilayah mana saja di Indonesia. (Wawancara Rizal Saputra Tgl 31 Mei 2018 Jam 11.26 WIB)

Hampir seluruh daerah di Indonesia. (Wawancara Septiyan A.K Tgl 02 Juni 2018 Jam 11.40 WIB)

Paling jauh papua, itu yang sering beli, kebanyakan sih luar jawa. (Wawancara Arista Kurnia Rohmah Tgl $04 \mathrm{Juni} 2018$ Jam WIB)

Sementara ini hanya sekitar jawa timur saja. (Wawancara Indra Tri Hutomo Tgl 06 Juni 2018 Jam 12.25 WIB)

Paling banyak dari pulau jawa, dan rata-rata reseller. (Wawancara Agus Danang S. Tgl 07 Juni 2018 Jam 12.25 WIB)

Semua kalangan, terutama mereka yang berasal dari Madiun tapi merantau di luar kota. (Wawancara Ahmad Tgl 09 Juni 2018 Jam 13.10 WIB)

Untuk masalah cakupan sih pada costumer otomotif (Wawancara Toha Ismail Tgl 11 Juni 2018 Jam 13.22 WIB)

Malah kebanyakan luar pulau jawa yang membeli di Agee Books karena lapak saya menjual software. (Wawancara Dewi Ana Tgl 25 Juni 2018 Jam 13.18 WIB)

Dari beberapa jawaban informan pengelola UMKM yang ada di aplikasi Bukalapakmenyatakan bahwa sebagian besar pengelola UMKM di Kota Madiun memberikan pendapat mengenai cakupan pasar dan pembelian terjauh dikirim di wilayah seluruh Indonesia. Dan yang paling sering ke Luar Jawa, karena mereka mengganggap harga jual barang atau produk di Jawa itu lebih murah daripada di luar Jawa jadi memungkin para konsumen untuk memilih produk yang dikirim dari pulau Jawa.

c) Pembayaran

1) Metode pembayaran untuk melakukan transaksi di aplikasi Bukalapak.

Hasil wawancara:

Kalau di Bukalapak kan sudah disediakan, ibaratnya sudah lengkap, dan merupakan transaksi murni karena tidak menerima transaksi di luar Bukalapak. Toko ini tidak bisa COD (Cash On Delivery) karena kami mempercayakan sepenuhnya pada Bukalapak. (Syarif Putranto A Tgl 28 Mei 2018 Jam 11.25 WIB)

Menurut saya penjual Bukalapak itu posisi tengah. Bukalapak sendiri menyediakan berbagai metode pembayaran antara lain transfer antar bank atau bisa juga via minimarket. Dana tersebut nanti ditampung di rekber (rekening bersama) Bukalapak. Jika di Bukalapak itu pokoknya aman. (Wawancara Maria Dita Tgl 30 Mei 2018 Jam 12.53 WIB)

Menggunakan transfer, di minimarket juga bisa. (Wawancara Rizal Saputra Tgl 31 Mei 2018 Jam 11.32 WIB)

Di Bukalapak sudah ada semuanya. (Wawancara Septiyan A.K Tgl 02 Juni 2018 Jam 11.43 WIB)

Dalam bertransaksi murni menggunakan system bukalapak, tidak menerima COD dan lainnya. (Wawancara Indra Tri Hutomo Tgl 06 Juni 2018 Jam 12.20 WIB)

Kalau metode pembayaran ototmatis disediakan langsung oleh bukalapak. (Wawancara Agus Danang S. Tgl 07 Juni 2018 Jam 12.40 WIB) 
Website : http://sosial.unmermadiun.ac.id/index.php/sosial

Tranfer via bank atau bisa pakai kartu kredit, dan yang disediakan bukalapak.

Transfer dan I-banking (Wawancara Ahmad Tgl 09 Juni 2018 Jam 13.15 WIB)

Ada beberapa sih mbak, misalnya transfer biasa, bisa juga bayar di minimarket. Bisa pakai kartu kredit pokoknya nggak ribet (Wawancara Toha Ismail Tgl 11 Juni 2018 Jam 13.28 WIB)

Kalau metode pembayaran di Bukalapak sudah lengkap kok mas. (Wawancara Dewi Ana Tgl 25 Juni 2018 Jam 13.23 WIB)

Dari beberapa jawaban informan pengelola UMKM yang ada di aplikasi Bukalapakmenyatakan bahwa sebagian besar pengelola UMKM di Kota Madiun dalam proses pembayaran pada transaksi jual beli di Bukalapak hampir semua menggunakan cara transfer via bank atau pun pada minimarket atau chanel lain yang bekerja sama dengan Bukalapak dan sebagian juga mengatakan bahwa pembayaran menggunakan aplikasi pembayaran yang disediakan oleh aplikasi Bukalapak itu sendiri.

2) Apakah harga produk yang ditawarkan sesuai dengan kualitas barang dan menunjang jumlah penjualan?

Hasil Wawancara:

Toko ini sudah cukup, karena di online store Bukalapak sendiri harga yang kami tawarkan sudah cukup murah. (Syarif Putranto A Tgl 28 Mei 2018 Jam 11.28 WIB)

Kami telah mementingkan pelanggan di Bukalapak, dengan penawaran baik otomatis pembeli memberikan feedback, dan nantinya akan menjadi tolak ukur di lapak kami karena kita jualan online mau nggak mau pembeli hanya bisa melihat gambar. (Wawancara Maria Dita Tgl 30 Mei 2018 Jam 12.56 WIB)

Sangat meningkat dan menunjang sih mas. Bisa dirasakan apabila kita menggunakan harga tersebut. Dan saya rasa harga sudah sesuai kualitas barang karena toko ini merupakan tangan pertama jadi sudah pasti murah dan bersaing. (Wawancara Rizal Saputra Tgl 31 Mei 2018 Jam 11.36 WIB)

Sudah memenuhi toko ini. (Wawancara Septiyan A.K Tgl 02 Juni 2018 Jam 11.48 WIB)

Sudah. (Wawancara Arista Kurnia Rohmah Tgl 04 Juni 2018 Jam 12.12 WIB)

Sudah sesuai. (Wawancara Indra Tri Hutomo Tgl 06 Juni 2018 Jam 12.28 WIB)

Sudah, karena sesuai dengan kualitas barang. (Wawancara Agus Danang S. Tgl 07 Juni 2018 Jam 12.45 WIB)

Sudah. (Wawancara Ahmad Tgl 09 Juni 2018 Jam 13.15 WIB)

Sudah (Wawancara Toha Ismail Tgl 11 Juni 2018 Jam 13.33 WIB)

Sudah. (Wawancara Dewi Ana Tgl 25 Juni 2018 Jam 13.25 WIB)

Dari beberapa jawaban informan pengelola UMKM yang ada di aplikasi Bukalapak menyatakan bahwa sebagian besar pengelola UMKM di Kota Madiun hampir seluruh pengelola dan penjual barang/produk di Bukalapak menyatakan bahwa harga dan kualitas barang sudah sesuai. Karena mereka menjual barang yang kualitasnya tidak abal-abal, dan rata-rata penjual di Bukalapak pada wilayah Kota Madiun ini merupakan penyuplai dan perusahaan tangan pertama produk, barang atau jasa.

Hasil wawancara dengan UMKM yang ada di Bukalapak, dengan menggunakan variabel Y, dengan indikator:

a) Total Pendapatan

1) Keuntungan yang diperoleh setiap bulannya dengan menggunakan aplikasi bukalapak.

Hasil wawancara:

Toko kami menggunakan standar ukur, apalagi 3 bulan terakhir lumayan meningkat dan yang lebih meningkat penjualan di toko kami adalah pada pembelian sparepartnya. (Syarif Putranto A Tgl 28 Mei 2018 Jam 11.33 WIB)

Alhamdulillah, sampai sekarang sudah cukup memuaskan. (Wawancara Maria Dita Tgl 30 Mei 2018 Jam 13.01WIB)

Sampai sekarang sudah cukup memuaskan. (Wawancara Rizal Saputra Tgl 31 Mei 2018 Jam 11.40 WIB)

Mengalami kenaikan setiap bulannya. (Wawancara Septiyan A.K Tgl 02 Juni 2018 Jam 11.53 WIB)

Jadi gini jualan itu kan kadang untung kadang rugi, misal untuk saat- saat tertentu seperti hari kartini dll mendapatkan omset yang tinggi. (Wawancara Arista Kurnia Rohmah Tgl 04 Juni 2018 Jam 12.16 WIB)

Untuk saat ini naik turun soalnya saya tidak memakai iklan ataupun paket push yang ada di bukalapak. (Wawancara Indra Tri Hutomo Tgl 06 Juni 2018 Jam 12.42 WIB)

Naik setiap bulannya. (Wawancara Agus Danang S. Tgl 07 Juni 2018 Jam 12.50 WIB)

Tidak tentu, ada kalanya omset sepi, stuck, tapi ada kalanya juga meningkat. (Wawancara Ahmad Tgl 09 Juni 2018 Jam 13.20 WIB)

Belum pasti karena otomotif itu berdasarkan prospek costumer. (Wawancara Toha Ismail Tgl 11 Juni 2018 Jam 13.40 WIB)

Naik mas, tapi nggk terlalu signifikan. (Wawancara Dewi Ana Tgl 25 Juni 2018 Jam 13.33 WIB)

Dari beberapa jawaban informan pengelola UMKM yang ada di aplikasi Bukalapak menyatakan bahwa sebagian besar pengelola UMKM di Kota Madiun mendapatkan keuntungan bersih dari hasil jualannya di Bukalapak tidak pasti setiap bulannya, namun ada beberapa yang merasa bahwa keuntungan sudah cukup naik dan memuaskan, dan adapun sebagian dari pelapak tersebut menyatakan bahwa keuntungannya kadang bergantung pada suatu momen tertentu.

2) Rata-rata kenaikan pendapatan seetiap bulannya dengan menggunakan aplikasi Bukalapak (dalam bentuk prosentase). Hasil wawancara: 
Website : http://sosial.unmermadiun.ac.id/index.php/sosial

Kisarannya dari bulan lalu itu hampir sama, antara bulan Mei - Juni dan sampai lebaran, ya kira-kira 10\% kenaikkan di Bukalapak sendiri, dan toko ini sudah mendapatkan feedback 400, sedangkan toko ini belum ada 1 tahun berdiri. (Syarif Putranto A Tgl 28 Mei 2018 Jam 11.40 WIB)

Kisarannya dari bulan lalu itu naik sampai $20 \%$ - 30 \% penjualan. (Wawancara Maria Dita Tgl 30 Mei 2018 Jam 13.09 WIB)

Kenaikkannya itu sampai $20 \%$ - 40 \% penjualan. (Wawancara Rizal Saputra Tgl 31 Mei 2018 Jam 11.45 WIB)

Sekitar 15\% setiap bulannya. (Wawancara Septiyan A.K Tgl 02 Juni 2018 Jam 11.45 WIB)

Untuk bulan kemarin itu bulan maret dibukalapak itu pembelinya sedikit tapi produk yang laku banyak, soalnya 1 orang ada yang beli 40 pcs. Jadi sekitar 150 pcs setiap bulannya. (Wawancara Arista Kurnia Rohmah Tgl 04 Juni 2018 Jam 12.20 WIB)

Masih sedikit mas, soalnya toko ini baru buka. (Wawancara Indra Tri Hutomo Tgl 06 Juni 2018 Jam 12.50 WIB)

40\% (Wawancara Agus Danang S. Tgl 07 Juni 2018 Jam 12.52 WIB)

Tidak tentu. $5 \%$ - $20 \%$ tergantung timming nya. Namun tidak selalu tiap bulan mengalami peningkatan. (Wawancara Ahmad Tgl 09 Juni 2018 Jam 13.26 WIB)

Jarang sih menghitung berapa persen yang jelas selalu untung mencapai 1 Juta - 1.5 Juta. (Wawancara Toha Ismail Tgl 11 Juni 2018 Jam 13.45 WIB)

Lumayan mas sekitar 10\% tiap bulannya. (Wawancara Dewi Ana Tgl 25 Juni 2018 Jam 13.35 WIB)

Dari beberapa jawaban informan pengelola UMKM yang ada di aplikasi Bukalapak menyatakan bahwa sebagian besar pengelola UMKM di Kota Madiun kenaikan pendapatan rata-rata setiap bulannya jika diprosentasekan maka sebanyak $15 \%$ sampai dengan $40 \%$ dan jika dirata-rata menurut nominal uang maka keuntungan pendapatan yang diperoleh sebesar 1.000 .000 ke atas setiap bulannya.

3) Kegunaan hasil pendapatan dari penjualan produk di Bukalapak.

Hasil wawancara:

Dibuat untuk gaji karyawan. (Syarif Putranto A Tgl 28 Mei 2018 Jam 11.35 WIB)

Menggaji karyawan dan menstock kembali barang yang sudah habis. (Wawancara Maria Dita Tgl 30 Mei 2018 Jam 13.11 WIB)

Menggaji karyawan serta produksi barang yang habis (Wawancara Rizal Saputra Tgl 31 Mei 2018 Jam 11.50 WIB)

Dibuat untuk menyetok lagi. (Wawancara Septiyan A.K Tgl 02 Juni 2018 Jam 11.49 WIB)

Mungkin ya saya tabung dan insyaalah untuk buka toko lagi. (Wawancara Arista Kurnia Rohmah Tgl 04 Juni 2018 Jam 12.30 WIB)

Untuk dibuat keperluan sehari - hari. (Wawancara Indra Tri Hutomo Tgl 06 Juni 2018 Jam 12.55 WIB)

Di modalkan kembali untung barang yang sudah habis. (Wawancara Agus Danang S. Tgl 07 Juni 2018 Jam 12.58 WIB)

Dari keuntungan tidak langsung diambil semua, biasanya saya menyisihkan untuk membeli push/promote dari Bukalapak untuk menaikkan peforma tampilan produk sehingga tetap berada di tampilan terdepan. (Wawancara Ahmad Tgl 09 Juni 2018 Jam 13.31 WIB)

Meningkatkan inovasi dan saling menyarankan customer ke jalan yang benar (Wawancara Toha Ismail Tgl 11 Juni 2018 Jam 13.50 WIB).

Dibuat untuk gaji karyawan. (Wawancara Dewi Ana Tg1 25 Juni 2018 Jam 13.40 WIB)

Dari beberapa jawaban informan pengelola UMKM yang ada di aplikasi Bukalapak menyatakan bahwa sebagian besar pengelola UMKM di Kota Madiun menggunakan sebagian besar keuntungan pendapatan untuk membeli kembali stok barang atau produk yang habis atau mungkin rusak, dan juga untuk menggaji para karyawan yang bekerja di lapak mereka.

b) Total Biaya

1) Modal pertama yang digunakan untuk berjualan di aplikasi Bukalapak

Hasil wawancara:

Awal gratis sih, lalu ada promo di Bukalapak untuk di upgrade ke premium jadi sebulannya 100.000 (Wawancara Syarif Putranto A Tgl 28 Mei 2018 Jam 11.38) WIB

Kalau untuk dropship itu pasti tidak ada modalnya, karena kami membantu jualannya orang. Beda dengan stock kalau ini kita harus keluar modal untuk menyetok barang dagangan. Ya, kurang lebih 300.000 lah. (Wawancara Maria Dita Tgl 30 Mei 2018 Jam 13.15 WIB)

Langsung pilih iklan yang sesuai dengan kemampuan toko. (Wawancara Rizal Saputra Tgl 31 Mei 2018 Jam 11.55 WIB) Modal pertama yaitu membeli upgrade lapak. (Wawancara Septiyan A.K Tgl 02 Juni 2018 Jam 11.53 WIB)

Modal saya 100 ribu tiap bulan untuk beli push di Bukalapak. 100 ribu dapat 250 push, soalnya kalau nggk gitu dagangan saya nggk keluar. (Wawancara Arista Kurnia Rohmah Tgl 04 Juni 2018 Jam 12.30 WIB)

Sama sekali tidak memakai modal, paling hanya membutuhkan koneksi internet. (Wawancara Indra Tri Hutomo Tgl 06 Juni 2018 Jam 13.10 WIB)

Modal awal digunakan untuk upgrade lapak dan paket push. (Wawancara Agus Danang S. Tgl 07 Juni 2018 Jam 13.05 WIB) 
Website : http://sosial.unmermadiun.ac.id/index.php/sosial

Nominal tepatnya saya lupa, tapi kurang lebih 100.000 sampai 200.000 (untuk membeli bahan-bahan juga mempersiapkan kemasan) (Wawancara Ahmad Tgl 09 Juni 2018 Jam 13.35 WIB)

Modal awal hanya 500. (Wawancara Toha Ismail Tgl 11 Juni 2018 Jam 13.55 WIB)

Paling Cuma koneksi internet. (Wawancara Dewi Ana Tgl 25 Juni 2018 Jam 13.48 WIB)

Dari beberapa jawaban informan pengelola UMKM yang ada di aplikasi Bukalapakmenyatakan bahwa sebagian besar pengelola UMKM di Kota Madiun pada saat membuka usaha di Bukalapak menggunakan modal pertama sebesar 100.000 yang mereka gunakan untuk membeli "push" pada Bukalapak agar barang yang mereka jual berada pada posisi paling atas pada pencarian di Bukalapak. Selain itu ada juga yang menggunakan modal uang untuk membeli produk kirakira sebesar 500.000 hingga 2.000.000 rupiah.

2) Pajak dibebankan pada UMKM yang berjualan di aplikasi Bukalapak.

Hasil wawancara:

Tidak ada. (Wawancara Syarif Putranto A Tgl 28 Mei 2018 Jam 11.40WIB)

Tidak ada. (Wawancara Maria Dita Tgl 30 Mei 2018 Jam 13.18 WIB)

Ada. Misal member mau bikin akun premium atau biasa pasti ada harga-harganya. (Wawancara Rizal Saputra Tgl 31 Mei 2018 Jam 12.00 WIB)

Tidak. (Wawancara Septiyan A.K Tgl 02 Juni 2018 Jam 11.30 WIB)

Nggak bayar, Cuma kita harus beli paket push untuk memaksimalkan jualan produk saya. (Wawancara Arista Kurnia Rohmah Tgl 04 Juni 2018 Jam 12.35 WIB)

Tidak (Wawancara Indra Tri Hutomo Tgl 06 Juni 2018 Jam 13.15 WIB)

Nggak ada, paling kalau mau upgrade baru bayar. (Wawancara Agus Danang S. Tgl 07 Juni 2018 Jam 13.10 WIB)

Tidak . (Wawancara Ahmad Tgl 09 Juni 2018 Jam 13.40 WIB)

Pastinya ada tapi nggak banyak karena itu pasti juga untuk gaji karyawan perusahaan Bukalapak (Wawancara Toha Ismail Tgl 11 Juni 2018 Jam 14.05 WIB)

Tidak ada. (Wawancara Dewi Ana Tgl 25 Juni 2018 Jam 13.50 WIB)

Dari beberapa jawaban informan pengelola UMKM yang ada di aplikasi Bukalapak menyatakan bahwa sebagian besar pengelola UMKM di Kota Madiun mengenai pajak atau tarif yang dikenakan dari pihak Bukalapak, tidak ada tarif yang harus dibayarkan. Namun ada beberapa yang menyatakan tarif pembayaran dari Bukalapak adalah untuk membeli "push" atau untuk mengupgrade akun penjualan di Bukalapak. (Hasil Wawancara, Kamis 05 Juli 2018)

\section{F. Hasil Analisa}

Sebagian besar pengelola UMKM di Kota Madiun merasa sangat puas dengan adanya Bukalapak, karena menurut mereka Bukalapak adalah situs jual beli yang terpercaya di Indonesia dan merasa terbantu karena mampu memberikan peningkatan pada nilai penjualan mereka. Sedangkan dari sisi nilai penjualan sebagian besar pengelola UMKM di Kota Madiun yang membuat mereka tertarik untuk menggunakan aplikasi Bukalapak adalah karena aplikasinya ini tidak berbayar, transaksi serta infonya mudah, keamanan transaksi serta info atau rahasia penting penjual dan pembeli terjaga. Dan yang pasti mudah dalam segi hal penggunaan untuk memasarkan produk mereka.

UMKM Kota Madiun yang menggunakan Bukalapak melakukan strategi penjualan dengan menggunakan paket "push" yang tersedia di Bukalapak itu sendiri, hal ini dilakukan karena paket itu berfungsi untuk menjadikan barang atau produk jualan pelapak akan berada pada puncak daftar pencarian barang satu Indonesia agar mudah di cari dan menguntungkan pelapak tersebut.

Sebagian besar UMKM di Kota Madiun yang menggunakan aplikasi Bukalapak dalam proses penjualannya memiliki cakupan pasar dan pembelian terjauh dikirim di wilayah seluruh Indonesia. Dan yang paling sering ke Luar Jawa, karena mereka mengganggap harga jual barang atau produk di Jawa itu lebih murah daripada di luar Jawa jadi memungkin para konsumen untuk memilih produk yang dikirim dari pulau Jawa.

Dalam transaksi di Bukalapak transaksi yang dilakukan untuk proses jual beli di Bukalapak hampir semua menggunakan cara transfer via bank atau pun pada minimarket atau chanel lain yang bekerja sama dengan Bukalapak dan sebagian juga mengatakan bahwa pembayaran menggunakan aplikasi pembayaran yang disediakan oleh aplikasi Bukalapak itu sendiri.

Para pengelola UMKM di Kota Madiun hampir seluruh penjual barang atau produk di Bukalapak menyatakan bahwa harga dan kualitas barang yang ditawarkan dan diiklankan tersebut sudah sesuai. Karena mereka menjual barang yang kualitasnya tidak abal-abal, dan rata-rata penjual di Bukalapak pada wilayah Kota Madiun ini merupakan penyuplai dan perusahaan tangan pertama produk, barang atau jasa. Meskipun barang dan harga sudah sesuai dengan kualitas yang terjamin mutunya namun keuntungan bersih dari hasil penjualan di Bukalapak tidak pasti setiap bulannya, sebab ada beberapa yang merasa bahwa keuntungan sudah cukup naik dan memuaskan, dan adapun sebagian dari pelapak tersebut menyatakan bahwa keuntungannya kadang bergantung pada suatu momen tertentu, seperti Lebaran, Natal, hari diskon nasional ataupun hari hari besar atau momen-momen tertentu yang membuat para konsumen jual beli online semakin meningkat.

UMKM di Kota Madiun yang ada di Bukalapak mengalami kenaikan pendapatan rata-rata setiap bulannya jika dimasukkan dalam prosentase maka sebanyak $15 \%$ sampai dengan $40 \%$ dan jika dirata-rata menurut nominal uang maka keuntungan pendapatan yang diperoleh sebesar 1.000 .000 ke atas setiap bulannya. Dari hasil keuntungan setiap bulannya tersebut maka keuntungan pendapatan tersebut digunakan untuk membeli kembali stok barang atau produk yang habis atau 
Website : http://sosial.unmermadiun.ac.id/index.php/sosial

mungkin rusak, dan juga untuk menggaji para karyawan yang bekerja di lapak mereka. Dalam membangun usaha online pertamanya para penjual online jual beli di aplikasi Bukalapak ini menggunakan modal pertama sebesar 100.000 yang mereka gunakan untuk membeli "push" pada Bukalapak agar barang yang mereka jual berada pada posisi paling atas pada pencarian di Bukalapak. Selain itu ada juga yang menggunakan modal uang untuk membeli produk kira-kira sebesar 500.000 hingga 2.000.000 rupiah.

Dan dari keseluruhan hasil wawancara, sebagian besar pengelola UMKM di Kota Madiun menyatakan mengenai pajak atau tarif yang dikenakan dari pihak Bukalapak, tidak ada tarif yang harus dibayarkan. Namun ada beberapa yang menyatakan tarif pembayaran dari Bukalapak adalah untuk membeli "push" atau untuk mengupgrade akun penjualan di Bukalapak itu sendiri.

\section{KESIMPULAN DAN SARAN}

Dari hasil wawancara penelitian dengan judul pengaruh e-commerce terhadap proses jual beli masyarakat saat ini khususnya pada penggunaan market online Bukalapak bahwa dapat dijelaskan beberapa pokok hasil wawancara adalah sebagai berikut:

1. Sebagian besar penjual online yang menggunakan Bukalapak menjelaskan bahwa proses jual beli online saat ini memilik faktor yang mendukung berkembangnya penjualan saat ini antara lain dengan menggunakan Bukalapak harga lebih terjangkau, cara penjualan dan pembayaran yang mudah dan dapat dilakukan diberbagai tempat dengan berbagai cara. Karena hanya dengan membuka aplikasi Bukalapak, penjual dan pembeli bisa dengan mudah memilih dan membayar barang yang diinginkan dengan transfer bank atau dengan membayarnya di minimarket-minimarket terdekat.

2. Mengahadapi pengaruh perkembangan jual beli online baik dari harga yang semakin meningkat setiap harinya dan juga pengaruh dari pesaing market online yang lainnya adalah dengan memberikan promosi pada setiap produk yang di jual di Bukalapak, selain itu memberikan pelayanan konsumen yang lebih ekstra baik lagi agar konsumen merasa dihargai. Dan selain itu memproduksi barang atau produk buatan sendiri yang belum pernah ada dipasaran.

3. Secara garis besar pengelola UMKM di Kota Madiun menyatakan mengenai pengaruh adanya Bukalapak adalah sangat memuaskan dan sangat baik dalam pelayanan. Dan sangat menguntungkan dalam penjualan dan proses jual beli online di masyarakat.

\section{VI.DAFTAR PUSTAKA}

Buku :

Hermawan Kartajaya, New Wave Marketing, Jakarta: PT. Gramedia Pustaka Utama, 2010, hlm 84)

Marla R. Stafford, Ronald J. Faber, Advertising Promotion and Media, New York: M.E. Sharpe, 2005, hlm 4, terjemahan

Internet :

Nystrom (May 2015) Teori Pemasaran from http://sukman21.blogspot.co.id/2015/05/teori-pemasaran.html (diakses online 20 November 2017, pukul 11.54)

Susanto (December 21, 2015) Pengertian E-Commerce Menurut Para Ahli from http://www.spengetahuan.com/2015/12/pengertian-e-commerce-menurut-paraahli-terlengkap.html (diakses online 21 November 2017, pukul 13.10)

Bukalapak from https://www.bukalapak.com/about (diaskes online 21 November,pukul 14.05)

Wikipedia from https://id.wikipedia.org/wiki/Bukalapak (diakses online 21 November, pukul 14.30)

E- Journal, Dewi Irmawati, 2011, Politeknik Negeri Sriwijaya

Marla R. Stafford, Ronald J. Faber, Advertising Promotion and Media, New York: M.E. Sharpe, 2005, hlm 4, terjemahan

E- Journal, Muhammad Amir Udin, 2014, Universitas Dian Nuswantoro, Semarang 